\title{
ANALISA KUALITAS WEBSITE SEKOLAH MENENGAH KEJURUAN NEGERI (SMKN) DI KOTA MAKASSAR DENGAN MENGGUNAKAN WEBQUAL MODIFIKASI
}

\author{
Muhammad Arafah, Tatik Maslihatin ${ }^{2}$ \\ Teknik Informatika STMIK AKBA ${ }^{1}$, Teknik Informatika STMIK AKBA ${ }^{2}$ \\ Email: arafah@akba.ac.id ${ }^{1}$, tatik@akba.ac.id ${ }^{2}$
}

\begin{abstract}
ABSTRAK
Keberadaan website sekolah sangat penting baik bagi siswa, sekolah maupun masyarakat. Namun keberadaan website sekolah tersebut belum pernah dianalisa untuk mengetahui sejauh mana kualitas layanan yang sudah diberikan kepada pengguna. Sehingga penelitian ini dilakukan untuk mengetahui kualitas layanan website Sekolah Menengah Kejuruan Negeri di kota Makassar. Metode yang digunakan dalam penelitian ini adalah deduktif kuantitatif dengan menggunakan Webqual versi 4.0 yang telah dimodifikasi dengan menambahkan dimensi kualitas antarmuka pengguna. Hasil penelitian menunjukkan bahwa terdapat gap yang cukup besar antara realitas web SMK dengan harapan pengguna akhir pada masingmasing dimensi. Gap paling besar terjadi pada dimensi kualitas layanan interaksi yaitu 0.98. Dan gap paling rendah terjadi pada dimensi kualitas antarmuka pengguna yaitu 0.82 .
\end{abstract}

\section{Kata Kunci : : Webqual, Kualitas, Pengukuran Kinerja, Sekolah Menengah Kejuruan}

\section{Pendahuluan}

Perkembangan Teknologi Informasi yang semakin pesat memacu semua elemen masyarakat dunia untuk ikut bergerak lebih cepat baik pada sektor pemerintahan, kesehatan, pariwisata, perekonomian dan pendidikan. Hal ini sejalan dengan misi rencana induk riset nasional 2015-2040 yaitu menciptakan masyarakat Indonesia yang inovatif berbasis iptek.

Salah satu bentuk pemanfaatan teknologi informasi di dunia pendidikan adalah adanya sistem informasi akademik dan website. Keberadaan sistem informasi akademik dan website menjadi bagian penting bagi kelangsungan suatu lembaga pendidikan. Karena sebuah lembaga pendidikan akan memiliki berbagai keunggulan kompetitif dan daya saing tinggi jika memiliki sistem informasi dan website yang baik.

Website adalah salah satu media penting dimana pengguna dapat menemukan semua jenis informasi yang berkaitan dengan bidang mereka. Peranan website suatu universitas tidak hanya terbatas sebagai media informasi namun juga merupakan salah satu barometer yang dipakai untuk mengukur kualitas perguruan tinggi tersebut (Puspitasari, 2013). Sedangkan website sekolah, saat ini lebih banyak digunakan untuk mengenalkan profil sekolah secara umum. Selain itu, siswa dapat mengakses materi pelajaran yang ada di sekolah serta masyarakat bisa mengakses data-data tentang sekolah tanpa harus datang langsung ke sekolah. 
Menurut Badan Pusat Statistik, saat ini jumlah Sekolah Menengah Kejuruan di Indonesia sebanyak 12.421 sekolah.( Maret 2017). Sedangkan jumlah Sekolah Menengah Kejuruan Negeri di Kota Makassar sebanyak 13 sekolah dan hanya 8 SMKN di kota Makassar yang memiliki website sekolah. Artinya jumlah website SMKN di kota Makassar hanya $61.5 \%$.

Keberadaan website sekolah sangat penting baik bagi siswa, sekolah maupun masyarakat. Namun keberadaan website sekolah tersebut belum pernah dianalisa untuk mengetahui sejauh mana kualitas layanan yang sudah diberikan kepada pengguna. Penelitian sebelumnya yang dilakukan oleh penulis menitikberatkan pada evaluasi kualitas layanan egovernment. (2016). Sedangkan penelitian yang dilakukan oleh Suci Ramadani dkk berfokus pada analisa kualitas layanan website Universitas Hasanuddin. (2015). Begitu pula Bayu Luhur Wicaksono, Adhi Susanto, dan Wing Wahyu Winarno melakukan penelitian terhadap Evaluasi Kualitas Layanan pada Website Pusdiklat BPK RI (2012).

Sehingga penelitian ini dilakukan untuk mengetahui kualitas layanan website Sekolah Menengah Kejuruan Negeri di kota Makassar. Penelitian ini fokus pada analisa website SMK-SMTI Makassar dan SMKN 2 Makassar yang merupakan sekolah yang sudah menggunakan second top level domain sch.id. SMK-SMTI Makassar dan SMKN 2 Makassar sebagai sekolah menengah kejuruan yang memiliki tata kelola yang cukup baik dan berupaya untuk memenuhi kebutuhan siswa, guru dan masyarakat dalam layanan informasi dalam bentuk pengadaan situs, Analisa website harus dilakukan karena dengan tidak adanya pengukuran kinerja kualitas layanan website tersebut maka sulit untuk dapat mengetahui tingkat kepuasan pengguna.

Metode yang digunakan dalam penelitian ini adalah deduktif kuantitatif dengan menggunakan Webqual versi 4.0 yang telah dimodifikasi dengan menambahkan dimensi kualitas antarmuka pengguna (user interface quality) dengan tiga dimensi utama WebQual 4.0, yaitu kualitas kegunaan (usability quality), kualitas informasi (information quality) dan kualitas layanan interaksi (service interaction quality). Penambahan dimensi kualitas antarmuka pengguna (user interface quality) dalam penelitian ini adalah untuk mengukur kualitas antarmuka website yang berkaitan dengan daya tarik visual website karena pengguna website akan melihat tampilan website sebagai interaksi pertama.

\section{Tinjauan Pustaka}

\subsection{Sekolah Menengah Kejuruan}

Sekolah Menengah Kejuruan (SMK) adalah salah satu bentuk satuan pendidikan formal yang menyelenggarakan pendidikan kejuruan pada jenjang pendidikan menengah sebagai lanjutan dari SMP/MTs atau bentuk lain yang sederajat atau lanjutan dari hasil belajar yang diakui sama/setara SMP/MTs. Di SMK terdapat banyak sekali program keahlian.

Menurut Badan Pusat Statistik, saat ini jumlah SMK di Indonesia mencapai 13.710 unit. Menurut data Kementerian Pendidikan dan Kebudayaan saat ini jumlah lulusan SMK per tahun mencapai 1,3 juta orang. Dari data itu jumlah siswanya mencapai 4,4 juta orang . Jumlah siswa SMK tercatat lebih banyak dibandingkan jumlah siswa SMA yang mencapai 4,3 juta orang. 
Sedangkan di Sulawesi Selatan, jumlah SMK mencapai 414 sekolah. Jumlah SMKN Di Kota Makassar sebanyak 13 sekolah dan hanya 8 SMKN yang memiliki website dengan domain id dan hanya 6 sekolah yang memiki domain sch.id, jadi terdapat beberapa website sekolah yang tidak menggunakan domain sch.id, dan kebanyakan dari website sekolah tersebut untuk kontennya tidak terupdate, dan terdapat sekolah yang konten dalam websitenya tidak berisi konten dari sekolah tersebut, sehingga kesan yang muncul yakni website sekolah tidak dikelola dengan baik dan terkesan asal ada. Sehingga tidak optimal dalam pemanfaatan website SMK. Padahal keberadaan website merupakan pintu gerbang bagi pihak luar untuk dapat mengetahui kondisi sekolah menengah kejuruan (SMK) tersebut, Dan jika website SMK dikelola dengan maksimal, keberadaan website akan memberikan keuntungan bagi pihak sekolah.

\subsection{Webqual Modification 4. 0}

Website (situs web) merupakan alamat (URL) yang berfungsi sebagai tempat penyimpanan data dan informasi dengan berdasarkan topik tertentu. (Sutarman, 2007). Menurut Boone \& Kurtz "Service quality refers to the expected perceived quality of service offering. It is primary determinant of customer satisfaction or disatisfaction".

WebQual merupakan salah satu metode atau teknik pengukuran kualitas website berdasarkan persepsi pengguna akhir. Metode ini merupakan pengembangan dari Servqual yang banyak digunakan sebelumnya pada pengukuran kualitas jasa. WebQual sudah mulai dikembangkan sejak tahun 1998 dan telah mengalami beberapa interaksi dalam penyusunan dimensi dan butir pertanyaannya.

Loiacono, dkk. mengembangkan metode WebQual dan memperkenalkan WebQualTM, sebuah ukuran kualitas website dengan 12 dimensi didasarkan pada tinjauan literatur yang luas dan wawancara dengan desainer dan pengunjung website. Lima kategori umum kualitas website yang didapatkan dari kajian literatur dan eksplorasi penelitian Loiacono, dkk. (2002), yaitu: ease of use, usefulness, entertainment, complementary relationship, dan customer service.

WebQual memiliki tiga dimensi yang mewakili kualitas suatu website, yaitu kegunaan (usability), kualitas informasi (information quality) dan kualitas interaksi (interaction quality).

\subsubsection{Usability}

Usability (kegunaan) adalah mutu yang berhubungan denngan rancangan site baik tampilan, kemudahan penggunaan, navigasi dan gambaran yang disampaikan kepada pengguna. Menurut Tullis dan Albert (2008), komponen umum usability antara lain:

- Adanya keterlibatan pengguna

- Pengguna melakukan suatu pekerjaan

- Pengguna melakukan sesuatu dengan adanya produk hal atau system

\subsubsection{Information Quality}

Information Quality adalah mutu dari isi / konten yang terdapat pada website, tepat atau tidaknya informasi yang disampaikan pada pengguna baik dari sisi akurasi, format maupun keterkaitannya. 


\subsubsection{Service Interaction}

Adalah mutu dari interaksi pelayanan yang dialami oleh pengguna ketika mereka menyelidiki site lebih dalam yang terwujud dengan adanya kepercayaan

pengguna dalam hal keamanan bertransaksi dan komunikasi. Maka berdasarkan ketiga dimensi tersebut, disusunlah indikator pada masing - masing masing dimensi antara lain :

Berikut adalah tabel deskripsi indikator pada tiap-tiap dimensi.

Tabel 1. Dimensi Kemudahan Penggunaan (Usability)

\begin{tabular}{|l|l|}
\hline No & \multicolumn{2}{|c|}{ Deskripsi Indikator } \\
\hline 1 & $\begin{array}{l}\text { Pengguna merasa mudah untuk } \\
\text { mempelajari pengoperasian website }\end{array}$ \\
\hline 2 & $\begin{array}{l}\text { Interaksi antara website dengan } \\
\text { pengguna jelas dan mudah } \\
\text { dipahami }\end{array}$ \\
\hline 3 & $\begin{array}{l}\text { Pengguna merasa mudah untuk } \\
\text { bernavigasi dalam website }\end{array}$ \\
\hline 4 & $\begin{array}{l}\text { Pengguna merasa website mudah } \\
\text { untuk digunakan }\end{array}$ \\
\hline 5 & $\begin{array}{l}\text { website memiliki tampilan yang } \\
\text { menarik }\end{array}$ \\
\hline 6 & Website mengandung kompetensi \\
\hline 7 & $\begin{array}{l}\text { Website menciptakan pengalaman } \\
\text { positif bagi pengguna }\end{array}$ \\
\hline
\end{tabular}

\begin{tabular}{|l|l|}
\hline 5 & $\begin{array}{l}\text { Website menyediakan informasi } \\
\text { yang mudah dimengerti }\end{array}$ \\
\hline 6 & $\begin{array}{l}\text { Website menyediakan informasi } \\
\text { yang detail }\end{array}$ \\
\hline 7 & $\begin{array}{l}\text { Website menyajikan informasi } \\
\text { dalam format yang tepat }\end{array}$ \\
\hline
\end{tabular}

Sumber:http//www.webqual.co.uk/instrum ent.htm

Tabel 3 Dimensi Kualitas Interaksi (Interaction Quality)

\begin{tabular}{|l|l|}
\hline No & \multicolumn{1}{|c|}{ Deskripsi Indikator } \\
\hline 1 & $\begin{array}{l}\text { Pengguna merasa aman untuk } \\
\text { melakukan transaksi }\end{array}$ \\
\hline 2 & $\begin{array}{l}\text { Pengguna merasa aman terhadap } \\
\text { informasi pribadinya }\end{array}$ \\
\hline 3 & $\begin{array}{l}\text { Website memberi ruang untuk } \\
\text { personalisasi }\end{array}$ \\
\hline 4 & $\begin{array}{l}\text { Website memberi ruang untuk } \\
\text { komunitas }\end{array}$ \\
\hline 5 & $\begin{array}{l}\text { Website memberi kemudahan } \\
\text { untuk berkomunikasi dengan } \\
\text { organisasi }\end{array}$ \\
\hline 6 & $\begin{array}{l}\text { Pengguna merasa yakin bahwa } \\
\text { barang/jasa akan dikirim } \\
\text { sebagaimana yang telah dijanjikan }\end{array}$ \\
\hline
\end{tabular}

Sumber:http//www.webqual.co.uk/instrum ent.htm

Tabel 2 Dimensi Kualitas Informasi (Information Quality)

\begin{tabular}{|l|l|}
\hline No & \multicolumn{2}{|c|}{ Deskripsi Indikator } \\
\hline 1 & $\begin{array}{l}\text { Website menyediakan informasi } \\
\text { yang akurat }\end{array}$ \\
\hline 2 & $\begin{array}{l}\text { Website menyediakan informasi } \\
\text { yang terpercaya }\end{array}$ \\
\hline 3 & $\begin{array}{l}\text { Website menyediakan informasi } \\
\text { tepat waktu }\end{array}$ \\
\hline 4 & $\begin{array}{l}\text { Website menyediakan informasi } \\
\text { yang relevan }\end{array}$ \\
\hline
\end{tabular}

Sedangkan dimensi Kualitas Antarmuka( User Interface quality) memiliki 6 indikator yang dapat digunakan, antara lain:

Tabel 4. Dimensi Kualitas Antarmuka ( User Interface quality)

\begin{tabular}{|l|l|}
\hline No & \multicolumn{1}{|c|}{ Deskripsi Indikator } \\
\hline 1 & $\begin{array}{l}\text { Website menggunakan gambar } \\
\text { yang tepat }\end{array}$ \\
\hline 2 & $\begin{array}{l}\text { Website menggunakan font (huruf) } \\
\text { yang sesuai }\end{array}$ \\
\hline 3 & $\begin{array}{l}\text { Website menggunakan warna yang } \\
\text { sesuai }\end{array}$ \\
\hline
\end{tabular}




\begin{tabular}{|l|lr|}
\hline 4 & $\begin{array}{l}\text { Website menggunakan desain } \\
\text { halaman yang sesuai }\end{array}$ \\
\hline 5 & $\begin{array}{l}\text { Link pada website bekerja dengan } \\
\text { baik }\end{array}$ \\
\hline 6 & $\begin{array}{l}\text { Kecepatan download pada } \\
\text { halaman website }\end{array}$ \\
\hline
\end{tabular}

\section{Metode Penelitian}

Metode yang digunakan dalam penelitian ini adalah deduktif kuantitatif dengan menggunakan Webqual versi 4.0 yang telah dimodifikasi dengan menambahkan dimensi kualitas antarmuka pengguna (user interface quality) dengan tiga dimensi utama WebQual 4.0, yaitu kualitas kegunaan (usability quality), kualitas informasi (information quality) dan kualitas layanan interaksi (service interaction quality). Penambahan dimensi kualitas antarmuka pengguna (user interface quality) dalam penelitian ini adalah untuk mengukur kualitas antarmuka website yang berkaitan dengan daya tarik visual website karena pengguna website akan melihat tampilan website sebagai interaksi pertama.

\subsection{Tahapan Penelitian}

Tahapan penelitian dalam mengimplentasikan kualitas layanan website SMK di Makassar adalah :

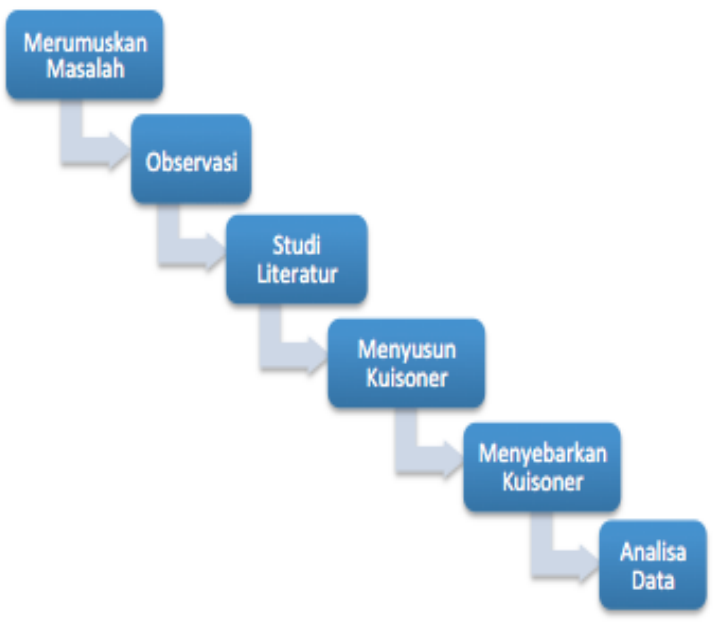

Gambar 1. Tahapan Penelitian

\subsection{Kerangka Pemikiran Penelitan}

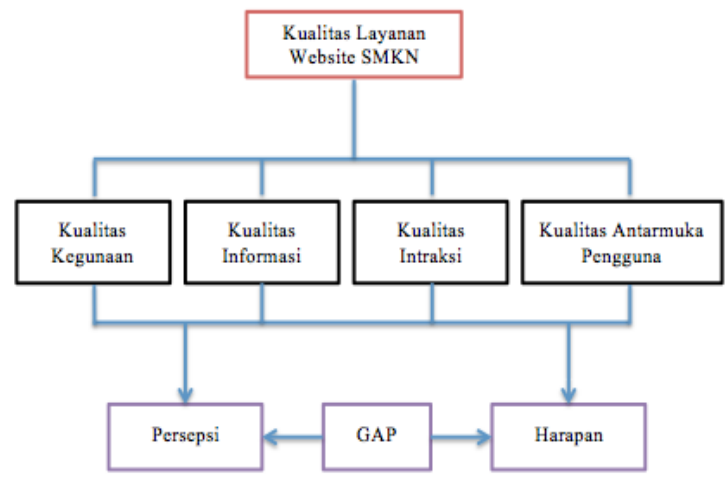

Gambar 1. Tahapan Penelitian

\subsection{Hipotesis Penelitian}

Hipotesis dalam penelitian ini, yaitu:

[H1]: Terdapat perbedaan antara persepsi aktual dan harapan ideal siswa SMKN pada dimensi kualitas kegunaan (usability) website

[H2]: Terdapat perbedaan antara persepsi aktual dan harapan ideal siswa SMKN pada dimensi kualitas informasi (information quality) website.

[H3]: Terdapat perbedaan antara persepsi aktual dan harapan ideal siswa SMKN pada dimensi kualitas layanan interaksi (service interaction quality) website.

[H4]: Terdapat perbedaan antara persepsi aktual dan harapan ideal siswa SMKN pada dimensi kualitas antarmuka pengguna (user interface quality) website.

\subsection{Metode Analisis}

Dalam penelitian ini, data primer kami peroleh dari hasil survey berupa penyebaran kuisoner yang diberikan kepada responden. Populasi dalam penelitian ini adalah siswa SMK-SMTI Makassar dan SMKN2 Makassar. Sehingga jumlah sampel yang ditetapkan sebanyak 126 responden. Sedangkan instrumen penelitian antara lain sebagai berikut. 
Tabel 6 . Instrumen Penelitian

\begin{tabular}{|c|c|c|}
\hline Variabel & Kode & Indikator \\
\hline \multirow{7}{*}{$\begin{array}{l}\text { Usability / } \\
\text { Kemudahan } \\
\text { Penggunaan }\end{array}$} & US1 & Pengguna dapat dengan mudah menggunakan website \\
\hline & US2 & Pengguna dapat dengan mudah berinteraksi dengan website \\
\hline & US3 & Website mudah untuk dinavigasi \\
\hline & US4 & Website mudah untuk digunakan \\
\hline & US5 & Website memiliki tampilan yang menarik \\
\hline & US6 & Website mengandung nilai kompetensi \\
\hline & US7 & Website menciptakan pengalaman positif bagi pengguna \\
\hline \multirow{7}{*}{$\begin{array}{l}\text { Information } \\
\text { Quality ( } \\
\text { Kualitas } \\
\text { Informasi) }\end{array}$} & $I Q 1$ & Website menyediakan informasi yang akurat \\
\hline & $I Q 2$ & Website menyediakan informasi yang terpercaya \\
\hline & IQ3 & Website menyediakan informasi tepat waktu \\
\hline & IQ4 & Website menyediakan informasi yang relevan \\
\hline & $I Q 5$ & Website menyediakan informasi yang mudah dimengerti \\
\hline & IQ6 & Website menyediakan informasi yang detail \\
\hline & $I Q 7$ & Website menyajikan informasi dalam format yang tepat \\
\hline \multirow{6}{*}{$\begin{array}{l}\text { Service } \\
\text { Interaction } \\
\text { Quality ( } \\
\text { Kualitas } \\
\text { Interaksi) }\end{array}$} & $S I 1$ & Pengguna merasa aman ketika melakukan transaksi \\
\hline & $S I 2$ & Pengguna merasa aman terhadap informasi pribadi \\
\hline & SI3 & Website memberikan ruang untuk personalisasi \\
\hline & SI4 & Website memberikan ruang untuk komunitas \\
\hline & SI5 & $\begin{array}{l}\text { Website memberikan kemudahan untuk berkomunikasi } \\
\text { dengan organisasi }\end{array}$ \\
\hline & SI6 & $\begin{array}{l}\text { Pengguna merasa yakin bahwa layanan yang diterima sesuai } \\
\text { dengan yang dijanjikan }\end{array}$ \\
\hline \multirow{6}{*}{$\begin{array}{l}\text { User Interface } \\
\text { Quality ( } \\
\text { Kualitas Antar } \\
\text { Muka) }\end{array}$} & UIQ1 & Website menggunakan gambar yang tepat \\
\hline & UIQ2 & Website menggunakan font (huruf) yang sesuai \\
\hline & UIQ3 & Website menggunakan warna yang sesuai \\
\hline & $U I Q 4$ & Website menggunakan desain halaman yang sesuai \\
\hline & UIQ5 & Link pada website bekerja dengan baik \\
\hline & UIQ6 & $\begin{array}{l}\text { Aktifitas download pada halaman website dapat dilakukan } \\
\text { dengan cepat }\end{array}$ \\
\hline
\end{tabular}

\subsection{Uji Validitas dan Uji Reliabilitas}

Instrumen penelitian tersebut kemudian dilakukan uji validitas dan uji reliabilitas. Hasil dari uji validitas terhadap instrument penelitian dapat dilihat pada tabel dibawah ini.

Tabel 7. Hasil uji vasiliditas

\begin{tabular}{|c|l|c|c|}
\hline \multicolumn{1}{|c|}{ Variabel } & Kode & \multicolumn{1}{c|}{$\begin{array}{c}\mathrm{R} \\
\text { tabel }\end{array}$} & $\begin{array}{c}\mathrm{R} \\
\text { hasil }\end{array}$ \\
\hline $\begin{array}{l}\text { Usability / } \\
\text { Kemudahan } \\
\text { Penggunaan }\end{array}$ & US1 & 0.1279 & 0.258 \\
\cline { 2 - 4 } & US2 & 0.1279 & 0.501 \\
\cline { 2 - 4 } & US3 & 0.1279 & 0.315 \\
\cline { 2 - 4 } & US4 & 0.1279 & 0.460 \\
\cline { 2 - 4 } & &
\end{tabular}

\begin{tabular}{|l|l|l|l|}
\cline { 2 - 4 } & US5 & 0.1279 & 0.483 \\
\cline { 2 - 4 } & US6 & 0.1279 & 0.347 \\
\cline { 2 - 4 } & US7 & 0.1279 & 0.415 \\
\hline \multirow{4}{*}{$\begin{array}{l}\text { Information } \\
\text { Quality } \\
\text { Kualitas } \\
\text { Informasi }\end{array}$} & IQ1 & 0.1279 & 0.363 \\
\cline { 2 - 4 } & IQ2 & 0.1279 & 0.469 \\
\cline { 2 - 4 } & IQ3 & 0.1279 & 0.433 \\
\cline { 2 - 4 } & IQ4 & 0.1279 & 0.377 \\
\cline { 2 - 4 } & IQ5 & 0.1279 & 0.376 \\
\cline { 2 - 4 } & IQ6 & 0.1279 & 0.532 \\
\cline { 2 - 4 } & IQ7 & 0.1279 & 0.420 \\
\hline \multirow{3}{*}{$\begin{array}{l}\text { Service } \\
\text { Interaction } \\
\text { Quality }\end{array}$} & SI1 & 0.1279 & 0.394 \\
\cline { 2 - 4 } & SI2 & 0.1279 & 0.488 \\
\cline { 2 - 4 } & SI1 & 0.1279 & 0.479 \\
\hline
\end{tabular}




\begin{tabular}{|c|c|c|c|}
\hline \multirow{3}{*}{$\begin{array}{l}\text { Kualitas } \\
\text { Interaksi) }\end{array}$} & SI4 & 0.1279 & 0.458 \\
\hline & SI5 & 0.1279 & 0.534 \\
\hline & SI6 & 0.1279 & 0.439 \\
\hline \multirow{6}{*}{$\begin{array}{l}\text { User } \\
\text { Interface } \\
\text { Quality ( } \\
\text { Kualitas } \\
\text { Antar Muka) }\end{array}$} & UIQ1 & 0.1279 & 0.703 \\
\hline & $U I Q 2$ & 0.1279 & 0.634 \\
\hline & UIQ3 & 0.1279 & 0.745 \\
\hline & UIQ4 & 0.1279 & 0.649 \\
\hline & UIQ5 & 0.1279 & 0.595 \\
\hline & UIQ6 & 0.1279 & 0.526 \\
\hline
\end{tabular}

$\mathrm{R}$ Tabel didapat dari $\mathrm{df}=$ jumlah kasus -2 , dengan tingkat signifikansi $5 \%$. Karena N kasus $=126$ maka $\mathrm{df}=126-2=124$. Maka $\mathrm{r}$ tabel $=0.1279$

* Jika r hasil positif, serta $r$ hasil > r tabel , maka variabel tersebut valid

* Jika r hasil negaitif, serta $r$ hasil < r tabel, maka variabel tersebut tidak valid

Berdasarkan hasil pada tabel diatas maka dapat dilihat bahwa semua variabel menunjukkan bahwa $r$ hasil positif dan $r$ hasil > $r$ tabel , maka semua variabel yang digunakan diatas adalah valid. Maka tahap selanjutnya adalah menentukan apakah variabel tersebut reliabel.

Tabel 8. Hasil Uji Reliabilitas

\begin{tabular}{|l|l|l|c|}
\hline \multicolumn{1}{|c|}{ Variabel } & Kode & $\mathrm{R}$ tabel & $\begin{array}{c}\mathrm{R} \\
\text { hasil }\end{array}$ \\
\hline $\begin{array}{l}\text { Usability / } \\
\text { Kemudahan } \\
\text { Penggunaan }\end{array}$ & $\mathrm{US}$ & 0.1279 & 0.674 \\
\hline $\begin{array}{l}\text { Information } \\
\text { Quality } \\
\text { (Kualitas } \\
\text { Informasi) }\end{array}$ & $\mathrm{IQ}$ & 0.1279 & 0.712 \\
\hline $\begin{array}{l}\text { Service } \\
\text { Interaction } \\
\text { Quality } \\
\text { (Kualitas } \\
\text { Interaksi) }\end{array}$ & $\mathrm{SI}$ & 0.1279 & 0.729 \\
\hline $\begin{array}{l}\text { User } \\
\text { Interface }\end{array}$ & $\mathrm{UIQ}$ & 0.1279 & 0.850 \\
\hline
\end{tabular}

\begin{tabular}{|l|l|l|l|}
\hline Quality & & & \\
(Kualitas & & & \\
Antar & & & \\
Muka) & & & \\
\hline
\end{tabular}

Jika $r$ hasil positif, serta $r$ hasil $>r$ tabel, maka variabel tersebut reliabel

* Jika r hasil negaitif, serta $r$ hasil < r tabel, maka variabel tersebut tidak reliable

Berdasarkan hasil pada tabel diatas maka kita bisa lihat bahwa semua variabel menunjukkan bahwa $r$ hasil positif dan $r$ hasil > $\mathrm{r}$ tabel, maka semua variabel yang digunakan diatas adalah reliabel.

\subsection{Uji Paired $t$ Sample}

Setelah tahap pengujian instrumen penelitian melalui uji validitas dan uji reliabilitas maka tahap selanjutnya adalah melakukan uji paired t sample. Data yang terkumpul akan diolah dalam teknik analisis uji beda t (Paired Samples T Test) untuk menganalisis hipotesis penelitian. Uji Paired $t$ sample berfungsi untuk mengetahui perbandingan nilai mean pada satu sample yang mengalami dua kondisi. Dalam hal ini penelitian ini bermaksud mengetahui bagaimana kondisi web SMKN menurut pengguna akhir. Realitas / persepsi dengan harapan pengguna akhir terhadap web SMKN tersebut. Sehingga uji Paired $\mathrm{t}$ sample ini dilakukan untuk menguji hipotesa apakah realitas sama dengan harapan pengguna akhir terhadap web tersebut. 


\subsection{Hasil Uji Hipotesis}

Tabel 10. Hasil Mean pada Kualitas Kegunaan (Usability)

\begin{tabular}{|l|l|l|l|}
\hline Variabel & \multicolumn{1}{|c|}{$\begin{array}{c}\text { Mean } \\
\text { Persepsi }\end{array}$} & $\begin{array}{c}\text { Mean } \\
\text { Harapan }\end{array}$ & $\begin{array}{c}\text { Mean } \\
\text { Difference }\end{array}$ \\
\hline US1 & 4.17 & 5.00 & -0.778 \\
\hline US2 & 4.16 & 4.91 & -0.754 \\
\hline US3 & 3.90 & 4.93 & -1.024 \\
\hline US4 & 4.21 & 4.90 & -0.698 \\
\hline US5 & 4.29 & 4.94 & -0.643 \\
\hline US6 & 4.05 & 4.94 & -0.897 \\
\hline US7 & 4.20 & 4.94 & -0.746 \\
\hline $\begin{array}{l}\text { Mean } \\
\text { Total }\end{array}$ & 4.08 & 4.93 & -0.85 \\
\hline
\end{tabular}

Tabel 11. Hasil Mean pada Kualitas Informasi (Information Quality)

\begin{tabular}{|l|l|l|l|}
\hline Variabel & $\begin{array}{l}\text { Mean } \\
\text { Persepsi }\end{array}$ & $\begin{array}{l}\text { Mean } \\
\text { Harapan }\end{array}$ & $\begin{array}{l}\text { Mean } \\
\text { Difference }\end{array}$ \\
\hline Iq1 & 4.13 & 4.94 & -0.810 \\
\hline Iq2 & 3.79 & 4.94 & -1.151 \\
\hline Iq3 & 3.79 & 4.94 & -1.151 \\
\hline Iq4 & 3.97 & 4.91 & -0.944 \\
\hline Iq5 & 4.23 & 4.94 & -0.706 \\
\hline Iq6 & 3.94 & 4.94 & -1.008 \\
\hline Iq7 & 4.10 & 4.94 & -0.849 \\
\hline Mean & 3.99 & 4.93 & -0.93 \\
Total & & & \\
\hline
\end{tabular}

Tabel 12. Hasil Mean pada Kualitas Layanan Interaksi (Service Interaction Quality)

\begin{tabular}{|l|l|l|l|}
\hline Variabel & $\begin{array}{l}\text { Mean } \\
\text { Persepsi }\end{array}$ & $\begin{array}{l}\text { Mean } \\
\text { Harapan }\end{array}$ & $\begin{array}{l}\text { Mean } \\
\text { Difference }\end{array}$ \\
\hline SI1 & 4.21 & 4.94 & -0.730 \\
\hline SI2 & 3.89 & 4.92 & -1.032 \\
\hline SI3 & 3.67 & 4.94 & -1.270 \\
\hline SI4 & 3.99 & 4.94 & -0.944 \\
\hline SI5 & 3.82 & 4.92 & -1.103 \\
\hline SI6 & 4.09 & 4.94 & -0.849 \\
\hline $\begin{array}{l}\text { Mean } \\
\text { Total }\end{array}$ & 3.94 & 4.93 & -0.98 \\
\hline
\end{tabular}

Tabel 13. Hasil Mean pada Kualitas Antarmuka Pengguna (User Interface Quality)

\begin{tabular}{|l|l|l|l|}
\hline Variabel & $\begin{array}{l}\text { Mean } \\
\text { Persepsi }\end{array}$ & $\begin{array}{l}\text { Mean } \\
\text { Harapan }\end{array}$ & $\begin{array}{l}\text { Mean } \\
\text { Difference }\end{array}$ \\
\hline Uiq1 & 4.22 & 4.94 & -0.714 \\
\hline Uiq2 & 4.06 & 4.94 & -0.881 \\
\hline Uiq3 & 4.13 & 4.94 & -0.810 \\
\hline Uiq4 & 4.17 & 4.92 & -0.754 \\
\hline Uiq5 & 4.21 & 4.94 & -0.738 \\
\hline Uiq6 & 3.84 & 4.91 & -1.071 \\
\hline $\begin{array}{l}\text { Mean } \\
\text { Total }\end{array}$ & 4.10 & 4.93 & -0.82 \\
\hline
\end{tabular}

Berdasarkan tabel diatas, maka dapat dilihat bahwa hasil analisis terhadap keseluruhan hipotesis dalam penelitian ini menunjukkan bahwa terdapat perbedaan rerata antara persepsi dan harapan ideal pada masing-masing dimensi. Hal ini mengindikasikan bahwa terdapat adanya gap antara realitas dan harapan pada masing-masing dimensi. 
Tabel 14. Hasil Uji Hipotesis

\begin{tabular}{|c|c|c|c|}
\hline \multirow{2}{*}{ Dimensi } & \multicolumn{2}{|c|}{ Mean } & $\begin{array}{c}\text { Mean } \\
\text { Difference }\end{array}$ \\
\hline usability & Persepsi & 4.08 & -0.85 \\
\cline { 2 - 3 } & Harapan & 4.93 & \\
\hline information quality & Persepsi & 3.99 & -0.93 \\
\hline service interaction quality & Harapan & 4.93 & \\
\hline & Persepsi & 3.94 & -0.98 \\
\hline user interface quality & Harapan & 4.93 & \\
\hline & Persepsi & 4.10 & -0.82 \\
\hline
\end{tabular}

Berdasarkan Tabel 14, dimensi kualitas antarmuka pengguna (user interface quality) adalah dimensi yang memiliki nilai mean difference yang paling tinggi diantara dimensi yang lain yaitu 0.82. Hal ini mengindikasikan bahwa kualitas layanan website SMK di Makassar cukup berhasil pada aspek kualitas antarmuka pengguna (user interface quality). Dimensi yang memiliki nilai mean difference yang paling rendah diantara dimensi yang lain yaitu -0.98 adalah dimensi kualitas layanan interaksi (service interaction quality). Hal tersebut mengindikasikan bahwa kualitas layanan interaksi (service interaction quality) merupakan aspek yang paling perlu ditingkatkan oleh pihak manajemen pengelola website dalam meningkatkan kualitas layanan website SMK agar sesuai dengan harapan pengguna.

Hasil penelitian menunjukkan bahwa terdapat gap yang cukup besar antara realitas web SMK dengan harapan pengguna akhir pada masing-masing dimensi. Gap paling besar terjadi pada dimensi kualitas layanan interaksi yaitu 0.98. Dan gap paling rendah terjadi pada dimensi kualitas antarmuka pengguna yaitu -0.82 .

\section{Penutup}

\subsection{Kesimpulan}

Berdasarkan penelitian yang dilakukan maka dapat disimpulkan bahwa:

Kualitas layanan website SMK di Makassar masih kurang. Hal ini bisa kita lihat bahwa gap antara persepsi realitas dan harapan masih mendekati dalam rentang $-1<\mathrm{n}<-0.5$. Terutama pada dimensi kualitas layanan interaksi. Hal ini menunjukkan bahwa layanan website SMK di Makassar kurang memberikan layanan interaksi yang baik antara pengguna dan website tersebut. Sedangkan untuk dimensi kualitas layanan antarmuka cukup bagus, karena memiliki nilai gap yang paling rendah diantara dimensi yang lain.

\subsection{Saran}

1. Dibutuhkan adanya upaya untuk meningkatkan kualitas layanan website SMK di Makassar terutama pada dimensi kualitas layanan interaksi. Hal ini menunjukkan bahwa layanan website SMK di Makassar kurang memberikan layanan interaksi yang baik antara pengguna dan website tersebut.

2. Harus ada upaya untuk memberikan pelatihan pada pihak pengelola website 
SMK oleh pihak-pihak terkait agar kualitas layanan website SMK di Makassar menjadi lebih baik.

\section{Daftar Pustaka}

Arifin, SC. 2015. Analisis Kualitas Layanan Website Universitas Hasanuddin Dengan Metode Webqual $4.0 \quad$ Modifikasi. Teknomatika. Vol.8 No.1. ISSN: 1979-7656

Kothainayaki, S., Sivakumaren, K.S. \& Gopalakrishnan, S., 2012. User Preferences on University Websites: A Study. Library Philosophy and Practice (ejournal), Paper 788 .

Loiacono, E.T., Watson, R.T. \& Goodhue, D.L., 2002. WebQual: A Measure of Website Quality. Marketing Theory and Applications, 13(3), pp. 432-438.

Maslihatin,T. 2016. Balanced Scorecard : Performance Measurement for $E$ Government. Journal of Theoretical and Applied Information Technology, Pakistan. Vol.90 No.2, pp.116-123, ISSN 1992-8645

Nasution, M., \& Mudjahidin, 2013. Analisis Kualitas Layanan Website Kantor Pelayanan Perbendaharaan Negara (KPPN) Surabaya I Dengan Metode WebQual. Seminar Nasional Sistem Informasi Indonesia, pp. 125-130.

Pabedinskaite,A. Akstinaite,V. 2013. Evaluation of Airport Service Quality. Procedia- Social and Behavioral Sciences.ISSN 398-409 Puspitasari, D., 2013. Kajian Kepuasan Terhadap Website Universitas Airlangga: Studi Komparasi antara
Pengguna Internal dan Pengguna Eksternal/Potensial. Thesis. Yogyakarta: Universitas Gadjah Mada.

Sari, N., 2013. Analisis Tingkat Kepuasan Mahasiswa Universitas Hasanuddin Terhadap Situs www.unhas.ac.id. Thesis. Makassar: Universitas Hasanuddin. Wicaksono, BL, 2012, “Evaluasi Kualitas Layanan Website Pusdiklat BPK RI menggunakan Metode Webqual Modifikasian dan Importance Performance Analysis”, Jurnal Media Ekonomi \& Teknologi Informasi,ISSN: 21 - 34, Vol. 19 No. 1, 2012. 